[21] Ingredienty dlia farmatsii. Neusilin ${ }^{\circledR}(2014)$. Farmatsevticheskaia otrasl, 5 (46), 25-27.

[22] Swain, S., Patra, C. N., Bhanoji Rao, M. E. (Eds.) (2016). Pharmaceutical Drug Delivery Systems and Vehicles. India: Woodhead Publishing India Pvt. Ltd., 209-210.

[23] Gumaste, S. G., Pawlak, S. A., Dalrymple, D. M., Nider, C. J., Trombetta, L. D., Serajuddin, A. T. M. (2013). Development of Solid SEDDS, IV: Effect of Adsorbed Lipid and Surfactant on Tableting Properties and Surface Structures of Different Silicates. Pharmaceutical Research, 30 (12), 3170-3185. doi: http://doi.org/10.1007/s11095-013-1114-4

[24] Hentzschel, C. M., Alnaief, M., Smirnova, I., Sakmann, A., Leopold, C. S. (2011). Tableting properties of silica aerogel and other silicates. Drug Development and Industrial Pharmacy, 38 (4), 462-467. doi: http://doi.org/10.3109/03639045.2011.611806

\title{
RESEARCH ON THE SELECTION OF EXCIPIENTS AS THE RATIONALE FOR THE COMPOSITION OF THE TABLETS WITH DRY EXTRACT OF SANGUISORBA OFFICINALIS
}

\author{
Lyudmila Shulga \\ shulga_ludmila@ukr.net \\ Kateryna Bezkrovna ${ }^{1}$ \\ katia2899@ukr.net \\ Nina Domar ${ }^{1}$ \\ domar1302@gmail.com \\ ${ }^{1}$ Department of General Pharmacy and Safety of Drugs \\ National University of Pharmacy \\ 53 Pushkinska str., Kharkiv, Ukraine, 61002
}

\begin{abstract}
The aim. The aim of the research was to study the effect of different groups of excipients on the pharmaco-technological propertiesof the powder mass for tabletting in the development of the composition of the tablets with dry extract of Sanguisorba officinalis for complex therapy of the gastrointestinal tract diseases.

Materials and methods. Objects of study - dry extract Sanguisorba officinalis, 25 excipients used in the production of tablets by the method of direct compression, grouped into five groups of factors (fillers based on sugars and microcrystalline cellulose, disintegrants, glidants and lubricants), samples of powder masses. Studies on the determination of pharmaco-technological properties (fluidity, bulk density, bulk density after shrinkage, degree of compressibility, Hausner ratio, and angle of repose) of the obtained powder masses were carried out according to the methods of the State Pharmacopoeia of Ukraine, Second edition. The method of mathematical planning of the experiment was used in the work, the obtained results were subjected to variance analysis, and the ranked series of advantages were placed, in which the excipients were placed in the sequence of their influence on the studied pharmaco-tecnological parameters.

Results and discussion. The influence of excipients (factors) on the pharmaco-technological properties (responses) of the powdered tablet masses with the construction of ranked benefits was studied using a five-factor experiment, a hyper-GraecoLatin square. The results of the analysis of variance showed that glidants have the greatest influence on the fluidity, the bulk density and the bulk density after shrinkage. Neusilin US 2 significantly affects the fluidity of the powder masses and Hausner ratio, the Talc having the greatest effect on the bulk density and the bulk density after shrinkage of the powder masses. The representative of the disintegrants group - Sodium starch glycolate most influences the compressibility index, the sugar-based filler Pearlitol $500 \mathrm{DC}-$ on the angle of repose.

Conclusions. The effect of 25 excipients on the pharmaco-technological characteristics of the powdered tablet masses with dry extract of Sanguisorba officinalis was studied. It was found that among the sugars-based fillers equally good results were shown
\end{abstract}


in the powder masses with Compri sugar, Tablettose 80 and Pearlitol 500 DC; among the microcrystalline cellulose based fillers is Prosolv 90; among glidants - Neusilin US 2; no comparison was made of the disintegrants and lubricant excipients from the studied list of leader substances. The results of the studies indicate the possibility of obtaining tablets by the direct compression method, and further study of their pharmaco-technological characteristics will allow to establish the optimal composition of excipients.

Keywords: Sanguisorba officinalis, dry extract, excipients, powder masses, mathematical planning of the experiment, tablets.

DOI: $10.21303 / 2504-5679.2020 .001195$

\section{Introduction}

The widespread spread of gastroenterological diseases makes it urgent to develop new drugs for pharmacotherapy. Thus, in the structure of the spread of morbidity by classes of diseases among the population of Ukraine, digestive diseases occupy the third place (10\%) and are second only to diseases of the circulatory system (31\%) and diseases of the respiratory system (20\%) [1].

The issue of therapy of gastroenterological diseases is given the attention of many specialists of medicine and pharmacy. Phytotherapy in the treatment of this group of diseases occupies a special place $[2,3]$. Scientists have reported the use of raw materials of such medicinal plants as aloe tree, blueberries, wormwood in ulcerative colitis; caraway seeds, medicinal chamomile, peppermint, medicinal lemon balm - with gastrointestinal cramps, gastritis, ulcers; calamus - in chronic dyspepsia, flatulence; angelica - for irritable bowel syndrome [4]. Medicinal plant raw materials of great burnet (Sanguisorba officinalis) are used in gastric and duodenal ulcers, gastric bleeding, colitis, enteritis [5].

In order to substantiate the development of a new drug for gastroenterology, marketing studies were conducted to analyse the pharmacotherapeutic group A "Digestives, incl. enzymes" (by ATC classification). It is established that the overall list of medicines is dominated by offers in the form of tablets and certain types of packaged medicinal herbal raw materials [6].

From the roots of Sanguisorba officinalis, which we defined as a promising medicinal plant raw material for the development of a medicinal product for gastroenterology [5], was obtained dry extract. The study of its pharmaco-technological properties, according to the results of which it is possible to predict the production of tablets by the method of direct compression, provided the use of rational excipients [7]. Pharmacological studies have shown gastroprotective activity of the dry extract of Sanguisorba officinalis [8], and microbiological screening - antibacterial action against the test strains of microorganisms $S$. aureus, E. coli, P. vulgaris, B. subtilis, P. aeruginosa and fungi of genus Candida [9]. The above points to the feasibility of creating a drug based on the dry extract of Sanguisorba officinalis for complex therapy of gastrointestinal diseases in the form of tablets, as a solid dosage form, which is well perceived by patients due to ease of use [10].

In the process of creating a medicinal product in a particular dosage form, considerable attention is paid to the selection of excipients, among which in the development of tablet formulations the attention of researchers is drawn to excipients, which are multicomponent mixtures - Ludipress, Prosolv and others $[11,12]$.

In the development of the specified solid dosage form, it is necessary to select such excipients that would give the powder mass of certain pharmaco-technological properties (flowability, extrusion), which are necessary for obtaining tablets by the method of direct compression, ensure their accuracy of dosage, strength, disintegration and stability during storage [13, 14].

In the development of drugs, in particular in the form of tablets, based on the dry extracts, determine their physico-chemical properties and pharmaco-tecnological characteristics. A number of dry extracts exhibit hygroscopic properties, complicating the process, causing the dry extract to become a viscous plastic mass $[15,16]$. This is prevented by adding to the tablet masses certain adjuvants capable of stabilizing hygroscopic objects.

One of the approaches used by scientists in determining the constituents of excipients in the development of tablet formulations is the use of methods of mathematical planning of the experiment, which allows you to quickly solve the search problem and obtain reliable results [17].

So, by the method of three-factor fractional plan of experiment based on Latin square $4 \times 4$ and further interpretation of results by means of analysis of variance, the influence of the nature of the binders, moisture content and fractional composition on the pharmaco-technological properties of granular 
tablet masses and matrix tablets containing dry extract of Vaccinium myrtillus was studied, and the optimal parameters for the manufacture of matrix tablets by the method of wet granulation were found [16].

The influence of 27 excipients on the on pharmaco-technological properties of the tablets with Pyrola rotundifolia extract obtained by the method of direct compression was studied using mathematical planning of the 2nd-order Graeco-Latin cube experiment [18].

The aim of the research. The aim of the study was to conduct a study to determine the excipients for the substantiation of the composition of the drug based on the dry extract of Sanguisorba officinalis in the form of tablets for complex therapy of the gastrointestinal tract diseases.

\section{Materials and methods}

The objects of study are the dry extract of Sanguisorba officinalis and 25 excipients (most of which are modern, widely used in the process of tablet production by the method of direct compression), which are divided into five groups (Table 1) [19, 20]. Research on the determination of pharmaco-technological propertiesof the obtained powder mass, namely: fluidity, bulk density, density after shrinkage, angle of repose, compressibility index and Hausner ratio, was carried out according to the methods of the State Pharmacopoeia of Ukraine, Second edition [13]. Five groups of factors were studied using one of the ANOVAs, namely the hyper-Graeco-Latin square. Each factor was studied at five levels [17].

When calculating the amount of excipients to obtain samples of the powder masses based on the fact that in one tablet the content of the dry extract of Sanguisorba officinalis is $40 \mathrm{mg}$, fillers based on sugars (factor A) - $24 \mathrm{mg}$, fillers based on microcrystalline cellulose (factor B) - 36.8 mg, disintegrants (factor C) - $9.6 \mathrm{mg}$, glidants (factor D) $-8.4 \mathrm{mg}$, lubricants (factor E) - $1.2 \mathrm{mg}$.

Table 1

Studied excipients in the development of tablets with the dry extract of Sanguisorba officinalis

\begin{tabular}{|c|c|c|}
\hline Factors & Factor level & Excipients \\
\hline \multirow{5}{*}{ A - sugars based fillers } & $a_{1}$ & Compri sugar \\
\hline & $a_{2}$ & Ludipress \\
\hline & $\mathrm{a}_{3}$ & Pearlitol 200 SD \\
\hline & $\mathrm{a}_{4}$ & Tablettose 80 \\
\hline & $a_{5}$ & Pearlitol 500 DC \\
\hline \multirow{5}{*}{$\begin{array}{l}\text { B - fillers based on microcrystalline } \\
\text { cellulose }\end{array}$} & $b_{1}$ & Microcelak 100 \\
\hline & $\mathrm{b}_{2}$ & Prosolv 90 \\
\hline & $b_{3}$ & Microcrystalline cellulose 101 \\
\hline & $\mathrm{b}_{4}$ & Microcrystalline cellulose 112 \\
\hline & $\mathrm{b}_{5}$ & Microcrystalline cellulose 200 \\
\hline \multirow{5}{*}{$\mathrm{C}$ - disintegrants } & $\mathrm{c}_{1}$ & Crospovidone XL 10 \\
\hline & $\mathrm{c}_{2}$ & Sodium croscarmellose \\
\hline & $\mathrm{c}_{3}$ & Pregelatinized starch \\
\hline & $\mathrm{c}_{4}$ & Potato starch \\
\hline & $\mathrm{c}_{5}$ & Sodium starch glycolate \\
\hline \multirow{5}{*}{ D - glidants } & $\mathrm{d}_{1}$ & Neusilin UFL 2 \\
\hline & $d_{2}$ & Neusilin US 2 \\
\hline & $\mathrm{d}_{3}$ & Talc \\
\hline & $\mathrm{d}_{4}$ & Aerosil 300 \\
\hline & $d_{5}$ & Aerosil 175 \\
\hline \multirow{5}{*}{$\mathrm{E}$ - lubricants } & $e_{1}$ & Magnesium stearate \\
\hline & $\mathrm{e}_{2}$ & Calcium stearate \\
\hline & $e_{3}$ & Stearic acid \\
\hline & $\mathrm{e}_{4}$ & Sodium lauryl sulfate \\
\hline & $\mathrm{e}_{5}$ & Polyethylene glycol- 4000 \\
\hline
\end{tabular}




\section{Results}

According to the experimental design matrix shown in Table 2, 25 powder mass samples were studied, that were obtained in two replicates. The results of the studies, which are also shown in Table 2, were subjected to analysis of variance, identified significant groups of excipients, compared them within the study group by the significance of the impact on pharmaco-technological characteristics.

Table 2

Experimental planning matrix for hyper-Graeco-Latin square and powder mass research results

\begin{tabular}{|c|c|c|c|c|c|c|c|c|c|c|c|c|c|c|c|c|c|}
\hline \multirow{2}{*}{ No. } & \multicolumn{5}{|c|}{ Factors/levels } & \multicolumn{12}{|c|}{ Response } \\
\hline & $A$ & 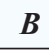 & & $D$ & $E$ & $\mathbf{y}_{1}$ & $\mathbf{y}_{1}^{\prime}$ & $\mathbf{y}_{2}$ & $\mathbf{y}_{2}^{\prime}$ & $\mathbf{y}_{3}$ & $\mathbf{y}_{3}^{\prime}$ & $\mathbf{y}_{4}$ & $\mathbf{y}_{4}^{\prime}$ & $\mathbf{y}_{5}$ & $\mathbf{y}_{5}^{\prime}$ & $\mathbf{y}_{6}$ & $\mathbf{y}_{6}^{\prime}$ \\
\hline 1 & $a_{1}$ & 1 & & $d_{1}$ & $e_{1}$ & 78.98 & 73.83 & .522 & 0.582 & 0.618 & 0.692 & 15.62 & 17.66 & 1.19 & 1.21 & 32 & 30 \\
\hline 2 & $a_{1}$ & $b_{2}$ & $c_{2}$ & $d_{2}$ & $e_{2}$ & 1899 & 1768 & 499 & 0505 & 0582 & 589 & 1419 & 1412 & 1.17 & 1.17 & 32 & 31 \\
\hline 3 & $a_{1}$ & $b_{3}$ & $c_{3}$ & $d_{3}$ & $e_{3}$ & 33.22 & 31.67 & 7 & 0.536 & 0.671 & 0.696 & 22. & 23.00 & 1.30 & 1.30 & 2 & 33 \\
\hline 4 & $a_{1}$ & $b_{4}$ & $c_{4}$ & $d_{4}$ & $e_{4}$ & 45.27 & 47.70 & 0.379 & 0.358 & 0.444 & 421 & 14.69 & 15.17 & 1.17 & 1.18 & 35 & 33 \\
\hline 5 & $a_{1}$ & $b_{5}$ & $c_{5}$ & $d_{5}$ & $e_{5}$ & 33 & 3917 & 58 & 448 & 3 & 542 & 1584 & 72 & 1.19 & 1 & 31 & 32 \\
\hline 6 & $a_{2}$ & $b_{1}$ & 2 & $d_{3}$ & $e_{4}$ & 34.57 & 33.95 & 0.561 & 0.555 & 0.693 & 0.680 & 18.96 & 18.36 & 1.23 & 1.22 & 36 & 35 \\
\hline 7 & $a_{2}$ & $b_{2}$ & $c_{3}$ & $d_{4}$ & $e_{5}$ & 8 & 778 & 0.349 & 0.353 & 0.435 & 0.438 & 19.77 & 4 & 1.25 & 4 & 33 & 32 \\
\hline 8 & $a_{2}$ & $b_{3}$ & ${ }^{4}$ & $d_{5}$ & $e_{1}$ & 6 & 69.96 & 0.373 & 37 & 0.492 & 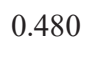 & 2 & 22.62 & 1.32 & 1.29 & 1 & 31 \\
\hline 9 & $a_{2}$ & $b_{4}$ & 5 & $d_{1}$ & $e_{2}$ & 41.08 & 40.38 & 0.552 & 0.556 & 0.690 & 0.698 & 19.93 & 20.24 & 1.25 & 1.26 & 21 & 23 \\
\hline 10 & $a_{2}$ & $b_{5}$ & $T$ & $d_{2}$ & $e_{3}$ & 21.48 & 2 & 0482 & 0.494 & 0.631 & 0627 & 2 & 21.12 & 1.31 & 1 & 22 & 24 \\
\hline 11 & $a_{3}$ & $b_{1}$ & s & $d_{5}$ & $e_{2}$ & 43.66 & 42.52 & 0.417 & 0.422 & 0.524 & 0.521 & 20.46 & 18.84 & 1.26 & 1.23 & 28 & 24 \\
\hline 12 & $a_{3}$ & $b_{2}$ & -4 & $d_{1}$ & $e_{3}$ & 23.81 & 23.43 & 0 & 0403 & 0584 & 0587 & 16.36 & 1603 & 1.20 & 1.19 & 28 & 26 \\
\hline 13 & $a_{3}$ & $b_{3}$ & 5 & $d_{2}$ & $e_{4}$ & 2 & 2 & 0.020 & 0.507 & 0.601 & 0.091 & 12.50 & 14.28 & 5 & 1.17 & 17 & 21 \\
\hline 14 & $a_{3}$ & $b_{4}$ & 1 & $d_{3}$ & $e_{5}$ & 59.86 & 60.84 & 0.487 & 0.489 & 0.644 & 0.633 & 24.23 & 20.06 & 1.32 & 1.31 & 25 & 27 \\
\hline 15 & $a_{3}$ & $b_{5}$ & 2 & $d_{4}$ & $e_{1}$ & 11660 & 11098 & 0.354 & 0356 & 157 & 0450 & 22.49 & 22.38 & 1.30 & 1.29 & 30 & 31 \\
\hline 16 & $a_{4}$ & $b_{1}$ & & $d_{2}$ & $e_{5}$ & 54.06 & 51.00 & 0.005 & 0.005 & 0.150 & 0.105 & 11.02 & 20.26 & 1.21 & 1.26 & 16 & 4 \\
\hline 17 & $a_{4}$ & $b_{2}$ & $v_{5}$ & $d_{3}$ & $e_{1}$ & 4123 & 3643 & 0631 & 0648 & 0696 & 0748 & 93 & 1333 & 1.10 & 1.15 & 27 & 27 \\
\hline 18 & $a_{4}$ & $b_{3}$ & $c_{1}$ & $d_{4}$ & $e_{2}$ & 89.00 & 92.04 & 0.383 & 0.391 & 0.493 & 0.499 & 22.26 & 21.66 & 1.29 & 1.28 & 24 & 24 \\
\hline 19 & $a_{4}$ & $b_{4}$ & & $d_{5}$ & $e_{3}$ & 80.49 & 75.64 & 0.439 & 0.446 & 0.560 & 0.567 & 21.50 & 21.25 & 1.28 & 1.27 & 26 & 25 \\
\hline 20 & $a_{4}$ & $b_{5}$ & $c_{3}$ & $d_{1}$ & $e_{4}$ & 163 & 15 & $55 \mathrm{C}$ & 0.56 & 8 & 0730 & 20 & 7 & 1.26 & 130 & 38 & 7 \\
\hline 21 & $a_{5}$ & $b_{1}$ & 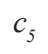 & $d_{4}$ & $e_{3}$ & 53.71 & 58.76 & 0.382 & 0.384 & 0.490 & 0.508 & 21.98 & 23.41 & 1.28 & 1.32 & 27 & 28 \\
\hline 22 & $a_{5}$ & $b_{2}$ & 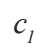 & $d_{5}$ & $e_{4}$ & 47.01 & 45.63 & 0.421 & 0.423 & 0.548 & 0.543 & 23.27 & 22.01 & 1.30 & 1.28 & 24 & 24 \\
\hline 23 & $a_{5}$ & $b_{3}$ & $c_{2}$ & $d_{1}$ & $e_{5}$ & 22.00 & 21.31 & 0.525 & 0.539 & 0.683 & 0.676 & 23.14 & 20.23 & 1.30 & 1.26 & 19 & 1 \\
\hline 24 & $a_{5}$ & $b_{4}$ & $c_{3}$ & $d_{2}$ & $e_{1}$ & 12.65 & 13.16 & 0.546 & 0.554 & 0.633 & 0.661 & 13.73 & 16.32 & 1.16 & 1.20 & 27 & 27 \\
\hline 25 & $a_{5}$ & $b_{5}$ & $c_{4}$ & $d_{3}$ & $e_{2}$ & 15.64 & 15.06 & 0.601 & 0.619 & 0.720 & 0.780 & 18.75 & 20.55 & 1.23 & 1.26 & 26 & 26 \\
\hline
\end{tabular}

Note: the first and the second repetitions respectively, where: $y_{1}$ and $y_{1}^{\prime}$-flowability of powder masses, s/100 g; $y_{2}$ and $y_{2}^{\prime}-$ bulk density of powder masses, $\mathrm{g} / \mathrm{cm}^{3} ; y_{3}$ and $y_{3}^{\prime}$-bulk density after shrinkage of powder masses, $\mathrm{g} / \mathrm{cm}^{3} ; y_{4}$ and $y_{4}^{\prime}$ - the degree of compressibility of the powder masses; $y_{5}$ and $y_{5}^{\prime}-$ Hausner ratio of powder masses; $y_{6}$ and $y_{6}^{\prime}-$ angle of repose of powder masses, deg

The influence of excipients on such indicator as flowability, which indicates the ability of solids (powders) to flow vertically under given conditions, was first of all determined. The effect of the five groups of factors on the flowability of powder mass of the dry extract of Sanguisorba officinalis can be reflected as follows: $\mathrm{D}>\mathrm{A}>\mathrm{E}>\mathrm{C}>\mathrm{B}$. Therefore, the most significant influence on the flowability of the masses for tableting is made by glidants, among which the best fluidity of the tableting mixtures is provided by Neusilin US $2(25.85 \mathrm{~s} / 100 \mathrm{~g})$, which showed advantages over Talc (36.25 s/100 g), Neusilin UFL 2 (41.33 s/100 g), Aerosil 175 (54.74 s/100 g) and Aerosil 300 (77.38 s/100 g) (Fig. 1). 


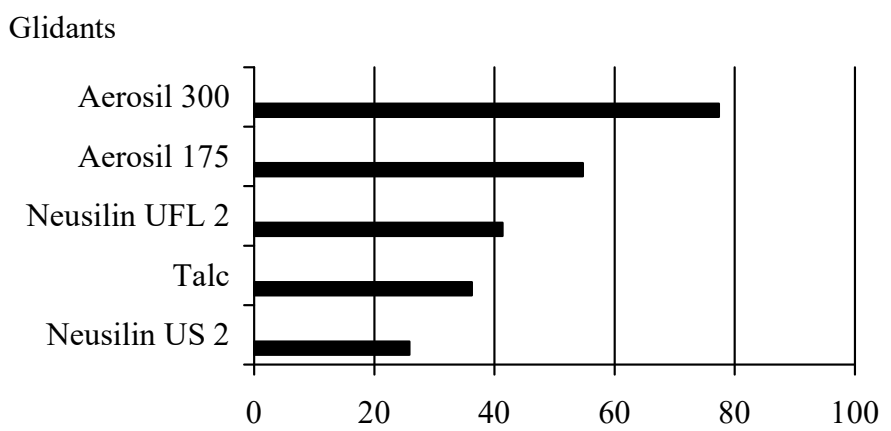

Flowability, s / 100g

Fig. 1. The effect of sliding substances on the flowability of powdered masses for tableting with the dry extract of Sanguisorba officinalis

In more detail, the effect of factor A - sugar-based fillers can be depicted as: Pearlitol 500 DC $(30.49 \mathrm{~s} / 100 \mathrm{~g})>$ Compri sugar $(42.18 \mathrm{~s} / 100 \mathrm{~g})>$ Ludipress $(49.10 \mathrm{~s} / 100 \mathrm{~g})>$ Pearlitol $200 \mathrm{SD}$ $(52.27 \mathrm{~s} / 100 \mathrm{~g})>$ Tablettose $80(61.50 \mathrm{~s} / 100 \mathrm{~g})$.

The ranged series of lubricants are as follows: Sodium lauryl sulfate $(38.37 \mathrm{~s} / 100 \mathrm{~g})>$ Calcium stearate $(41.61 \mathrm{~s} / 100 \mathrm{~g})>$ Stearic acid $(42.40 \mathrm{~s} / 100 \mathrm{~g})>$ Polyethylene glycol-4000 $(51.00 \mathrm{~s} / 100 \mathrm{~g})>$ $>$ Magnesium stearate $(62.18 \mathrm{~s} / 100 \mathrm{~g})$.

Among the disintegrants, the best flowability of powdered masses was with Sodium starch glycolate $(38.72 \mathrm{~s} / 100 \mathrm{~g})$, which takes precedence over Potato starch (42.05 s/100 g), Pregelatinized starch (42.52 s/100 g), Sodium croscarmellose (53.22 s/100 g) and Crospovidone XL 10 (59.05 s/100 g).

The influence of factor B - fillers based on microcrystalline cellulose is shown next: Prosolv $90(41.40 \mathrm{~s} / 100 \mathrm{~g})>$ Microcrystalline cellulose $200(46.46 \mathrm{~s} / 100 \mathrm{~g})>$ Microcrystalline cellulose $101(46.82 \mathrm{~s} / 100 \mathrm{~g})>$ Microcrystalline cellulose $112(47.71 \mathrm{~s} / 100 \mathrm{~g})>$ Microcelac 100 (53.17 s/100 g).

The next technological parameter that was defined is the bulk density, which expresses the ratio of the mass of the untapped sample to its volume, including the contribution of the interparticle free volume. It measured in a graduated cylinder. The ranked series is as follows: $\mathrm{D}>\mathrm{A}>\mathrm{C}>\mathrm{B}>\mathrm{E}$. The most significant effect on the bulk density for tableting is caused by glidants, among which the best bulk density of the mixtures is provided by Talc $\left(0.564 \mathrm{~g} / \mathrm{cm}^{3}\right)$, which showed advantages over Neusilin UFL 2 $\left(0.538 \mathrm{~g} / \mathrm{cm}^{3}\right)$, Neusilin US $2\left(0.532 \mathrm{~g} / \mathrm{cm}^{3}\right)$, Aerosil $175\left(0.422 \mathrm{~g} / \mathrm{cm}^{3}\right)$, Aerosil $300\left(0.369 \mathrm{~g} / \mathrm{cm}^{3}\right)$ (Fig. 2).

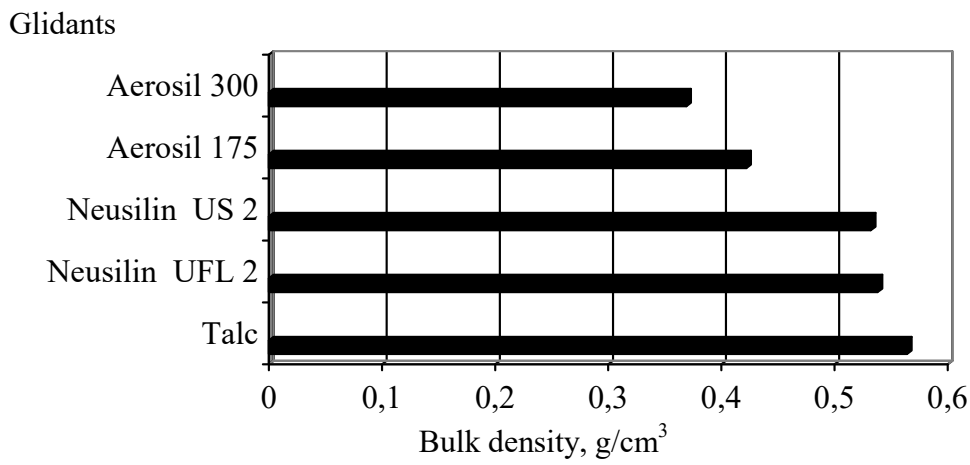

Fig. 2. The effect of glidants on the bulk density of the powder masses for tabletting with the dry extract of Sanguisorba officinalis

The effect of sugars-based fillers on the bulk density is as follows: Tablettose $80\left(0.527 \mathrm{~g} / \mathrm{cm}^{3}\right)>$ $>$ Pearlitol 500 DC $\left(0.499 \mathrm{~g} / \mathrm{cm}^{3}\right)>$ Compress sugar $\left(0.480 \mathrm{~g} / \mathrm{cm}^{3}\right)>$ Ludipress $\left(0.465 \mathrm{~g} / \mathrm{cm}^{3}\right)>$ $>$ Pearlitol $200 \mathrm{SD}\left(0.454 \mathrm{~g} / \mathrm{cm}^{3}\right)$.

In the study of the effect of factor $\mathrm{C}$ (disintegrants) on the bulk density the following results were obtained: Sodium starch glycolate $\left(0.509 \mathrm{~g} / \mathrm{cm}^{3}\right)>$ Potato starch $\left(0.489 \mathrm{~g} / \mathrm{cm}^{3}\right)>$ Starch pregelatinized $\left(0.482 \mathrm{~g} / \mathrm{cm}^{3}\right)>$ Croscarmellose sodium $\left(0.478 \mathrm{~g} / \mathrm{cm}^{3}\right)>$ Crospovidone XL $10\left(0.467 \mathrm{~g} / \mathrm{cm}^{3}\right)$. 
The effect of factor B - microcrystalline cellulose based fillers on the bulk density is depicted as follows: Microcelac $100\left(0.503 \mathrm{~g} / \mathrm{cm}^{3}\right)>$ Microcrystalline cellulose $200\left(0.494 \mathrm{~g} / \mathrm{cm}^{3}\right)>$ $>$ Microcrystalline cellulose $112\left(0.481 \mathrm{~g} / \mathrm{cm}^{3}\right)=$ Prosolv $90\left(0.481 \mathrm{~g} / \mathrm{cm}^{3}\right)>$ Microcrystalline cellulose $101\left(0.467 \mathrm{~g} / \mathrm{cm}^{3}\right)$.

There were following ranked a number of advantages of lubricants for the bulk density: Calcium stearate $\left(0.495 \mathrm{~g} / \mathrm{cm}^{3}\right)>$ Magnesium stearate $\left(0.494 \mathrm{~g} / \mathrm{cm}^{3}\right)>$ Polyethylene glycol-4000 $\left(0.486 \mathrm{~g} / \mathrm{cm}^{3}\right)>$ Sodium lauryl sulfate $\left(0.485 \mathrm{~g} / \mathrm{cm}^{3}\right)>$ Stearic acid $\left(0.466 \mathrm{~g} / \mathrm{cm}^{3}\right)$.

Another important indicator for direct compression of tablets is the density of powders after shrinkage. The ranked range of the influence of factors on the determined parameter of the samples mixtures with the dry extract of Sanguisorba officinalis is reflected as follows: $D>A>B$, with the statistical insignificance of factors $\mathrm{E}$ and $\mathrm{C}$. The most significant effect on the density of the powders for tableting after shrinkage is made by glidants, among the designated group the best bulk density of mixtures is provided by Talc $\left(0.696 \mathrm{~g} / \mathrm{cm}^{3}\right)$, which showed advantages over Neusilin UFL 2 $\left(0.667 \mathrm{~g} / \mathrm{cm}^{3}\right)$, Neusilin US $2\left(0.641 \mathrm{~g} / \mathrm{cm}^{3}\right)$, Aerosil $175\left(0.532 \mathrm{~g} / \mathrm{cm}^{3}\right)$, Aerosil $300\left(0.464 \mathrm{~g} / \mathrm{cm}^{3}\right)($ Fig. 3).

Tablettose $80\left(0.649 \mathrm{~g} / \mathrm{cm}^{3}\right)$ has the greatest influence on the bulk density after shrinkage of powdered powders among sugar-based fillers, followed by Pearlitol 500 DS $\left(0.624 \mathrm{~g} / \mathrm{cm}^{3}\right)$, Ludipress $\left(0.586 \mathrm{~g} / \mathrm{cm}^{3}\right)$, Compri sugar $\left(0.580 \mathrm{~g} / \mathrm{cm}^{3}\right)$ and Pearlitol $200 \mathrm{SD}\left(0.560 \mathrm{~g} / \mathrm{cm}^{3}\right)$.

Glidants

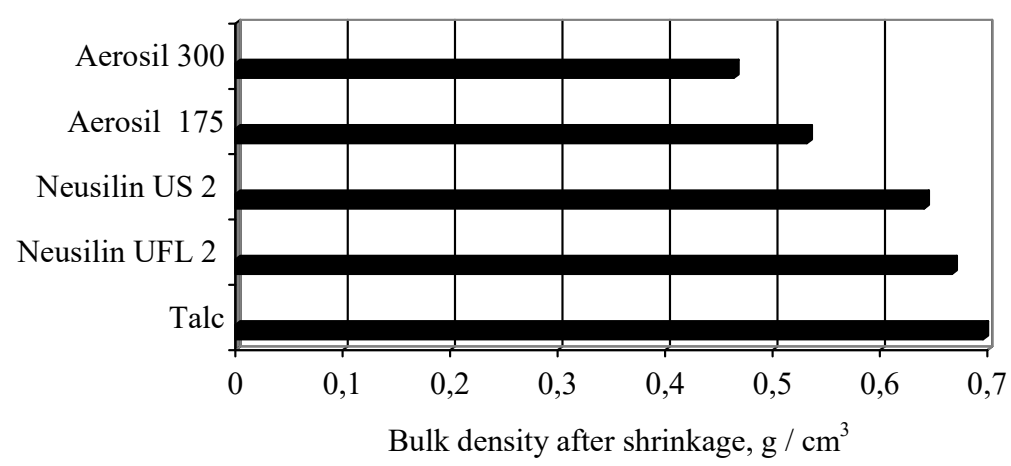

Fig. 3. The effect of glidants on the bulk density of powdered masses for tableting after shrinkage with the dry extract of Sanguisorba officinalis

The effect of factor B - microcrystalline cellulose-based fillers on the bulk density of the powder masses after shrinkage is as follows: Microcelac $100\left(0.503 \mathrm{~g} / \mathrm{cm}^{3}\right)>$ Microcrystalline cellulose $200\left(0.494 \mathrm{~g} / \mathrm{cm}^{3}\right)>$ Microcrystalline cellulose $112\left(0.481 \mathrm{~g} / \mathrm{cm}^{3}\right)=\operatorname{Prosolv} 90\left(0.481 \mathrm{~g} / \mathrm{cm}^{3}\right)>$ $>$ Microcrystalline cellulose $101\left(0.467 \mathrm{~g} / \mathrm{cm}^{3}\right)$.

Further, the index of compressibility was calculated. The ranked range of the influence of the factors is presented as follows: $\mathrm{C}>\mathrm{B}>\mathrm{D}>\mathrm{A}>\mathrm{E}$. It is determined that a significant effect on this indicator has a disintegrants. The lowest among which are powder masses when using Sodium starch glycolate (16.80), which has advantages over Potato starch (18.61), Sodium croscarmellose (19.66), Pregelatinized starch (19.81) and Crospovidone XL 10 (21.14) (Fig. 4).

The effect of microcrystalline cellulose based fillers can be illustrated by the following rank order: Prosolv 90 (16.8) > Microcrystalline cellulose 112 (18.7) > Microcelac 100 (19.2) > Microcrystalline cellulose 200 (20.5) > Microcrystalline cellulose 101 (20.7).

The effect of factor D - glidants on the compressibility indicator is as follows: Neusilin US 2 (16.73) > Talc (18,95) > Neusilin UFL 2 (19.28) > Aerosil 300 (20.33) > Aerosil 175 (20.73).

Lowest rate of fillers based on sugars compressibility parameter has Compri sugar (17.04), which takes precedence over Pearlitol 200 SD (18.76), Tablettose 80 (19.05), Pearlitol DC 500 (20.34) and Ludipress (20.82).

The effect of lubricants on the compressibility index is shown in the following row: Magnesium stearate $(17.78)>$ sodium lauryl sulfate $(18.28)>$ Calcium stearate $(19.10)>$ Polyethylene glycol-4000 (19.75) > Stearic acid (21.11). 
Disintegrants

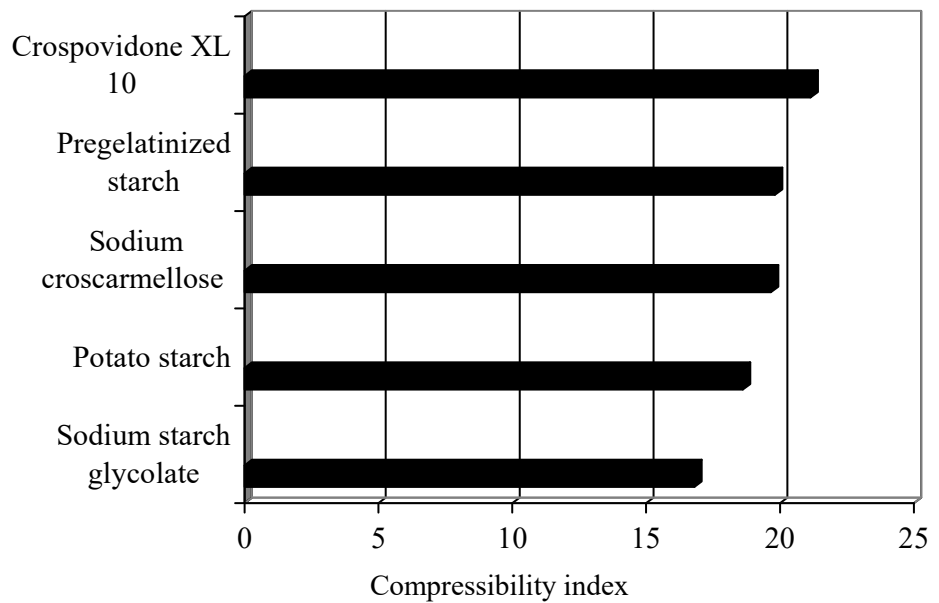

Fig. 4. The effect of disintegrants on the compressibility index of the powder masses for tableting with the dry extract of Sanguisorba officinalis

The tendency of the powder to be compressed can be estimated by the compressibility index and the Hausner ratio, for the calculation of which the obtained values of the bulk volume before shrinkage and bulk volume after shrinkage were taken. Therefore, the next parameter for determining pharmaco-technological indicators is the Hausner ratio.

The ranked range of the influence of factors on the determined pharmaco-technological index of the mixtures with the dry extract of Sanguisorba officinalis can be expressed as follows: $\mathrm{D}>\mathrm{A}>\mathrm{E}>\mathrm{C}>\mathrm{B}$. Therefore, the most significant influence on the Hausner ratio is exerted by glidants, and the ranked series is as follows: Neusilin US 2 (1.21) > Neusilin UFL 2 (1.24)=Talc (1.24) > $>$ Aerosil 300 (1.26)=Aerosil 175 (1.26) (Fig. 5).

The effect of sugars-based fillers on the Hausner ratio is as follows: Compri sugar (1.21) > $>$ Tablettose 80 (1.24)=Pearlitol 200 SD (1.24) > Pearlitol 500 DC (1.26) > Ludipress (1.26).

The effects of lubricants are shown as follows: Magnesium stearate (1.22) $>$ Sodium lauryl sulfate $(1.23)>$ Calcium stearate (1.24) > Polyethylene glycol-4000 (1.26) > Stearic acid (1.27).

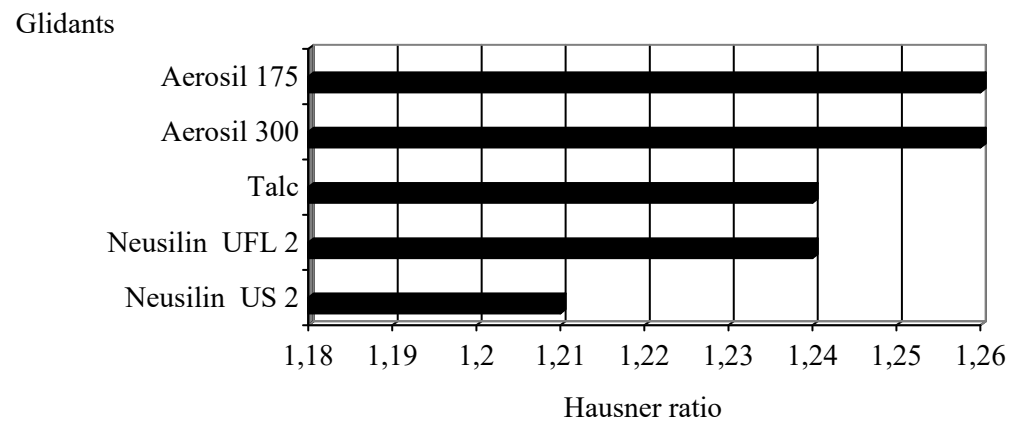

Fig. 5. Effect of glidants on Hausner ratio of powder masses for tabletting with the dry extract of Sanguisorba officinalis

Sodium starch glycolate (1.21) is the most preferred as disintegrant, then Potato starch (1.23) > $>$ Sodium croscarmellose $(1.25)=$ Pregelatinized starch $(1.25)>$ Crospovidone XL 10 (1.28).

The effect of microcrystalline cellulose based excipients is as follows: Prosolv $90(1.21)>\mathrm{Mi}-$ crocelac $100(1.24)=$ Microcrystalline cellulose $112(1.24)>$ Microcrystalline cellulose $200(1.26)>$ $>$ Microcrystalline cellulose 101 (1.27).

The next indicator is the angle of repose, which is another characteristic of the fluidity of the powder masses and characterizes their ability to obtain tablets by direct compression. The smaller the angle of repose, the greater the ability of the powder masses to press. 
The ranked range of the effects of factors on the determined pharmaco-tecnological index of mixtures with the dry extract of Sanguisorba officinalis can be expressed as follows: $\mathrm{A}>\mathrm{D}>\mathrm{C}>\mathrm{E}>\mathrm{B}$. Therefore, the sugars-based fillers have the most significant effect on the angle of repose for tableting. The smallest of the angles of repose tableting mixtures with the dry extract of Sanguisorba officinalis among the indicated excipients was provided by Pearlitol $500 \mathrm{DC}\left(24.9^{\circ} \mathrm{C}\right)$, which showed an advantage over Tablettose $80\left(25.8^{\circ} \mathrm{C}\right)$, Pearlitol 200 SD $\left(25.9^{\circ} \mathrm{C}\right)$, Ludipress $\left(28.8^{\circ} \mathrm{C}\right)$, Compri sugar $\left(32.10^{\circ} \mathrm{C}\right)$ (Fig. 6).

The influence of glidants on the angle of repose is depicted as follows: Neusilin US 2 $\left(23.3^{\circ} \mathrm{C}\right)>$ Neusilin UFL $2\left(27.5^{\circ} \mathrm{C}\right)>$ Aerosil $175\left(27.6^{\circ} \mathrm{C}\right)>$ Talc $(29.4)$ Aerosil $300\left(29.7^{\circ} \mathrm{C}\right)$.

Among the disintegrants, Crospovidone XL $10\left(25.6^{\circ} \mathrm{C}\right)$ and sodium starch glycolate $\left(25.6^{\circ} \mathrm{C}\right)$ showed the best result on the angle of repose. Subsequent positions are Potato starch $\left(26.6^{\circ} \mathrm{C}\right)$, Sodium croscarmellose $\left(28.6^{\circ} \mathrm{C}\right)$ and Pregelatinized starch $\left(31.1^{\circ} \mathrm{C}\right)$.

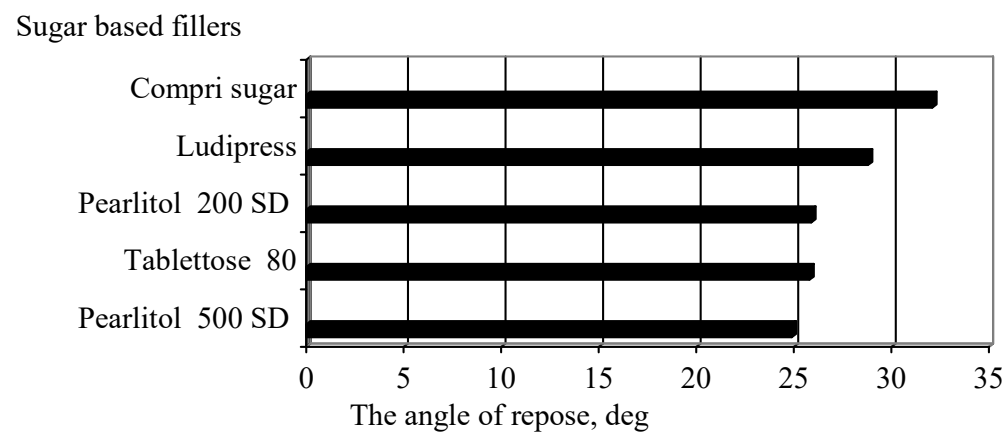

Fig. 6. The effect of sugar-based fillers on the angle of repose of powder masses for tableting with the dry extract of Sanguisorba officinalis

The effect of lubricants on the angle of repose can be represented by the following series: Polyethylene glycol-4000 $\left(25^{\circ} \mathrm{C}\right)>$ Calcium stearate $\left(25.9^{\circ} \mathrm{C}\right)>$ Stearic acid $\left(27.1^{\circ} \mathrm{C}\right)>$ Magnesium stearate $\left(29.3^{\circ} \mathrm{C}\right)>$ Sodium lauryl sulfate $\left(30.2^{\circ} \mathrm{C}\right)$.

The effect of microcrystalline cellulose-based excipients on the angle of repose powder masses for tableting can be illustrated as follows: Microcrystalline cellulose $101\left(25.5^{\circ} \mathrm{C}\right)>$ Microcrystalline cellulose $112\left(26.9^{\circ} \mathrm{C}\right)>$ Microcelac $100\left(27^{\circ} \mathrm{C}\right)>$ Prosolv $90\left(28.4^{\circ} \mathrm{C}\right)>$ Microcrystalline cellulose $200\left(29.7^{\circ} \mathrm{C}\right)$.

\section{Discussion}

The application of the method of mathematical planning of the experiment in determining the constituents of excipients of powder masses with the dry extract of Sanguisorba officinalis, as well as in the corresponding experiments on different plans of dispersion analysis in substantiating the components of other innovative drugs, allows to establish the influence of qualitative factors (groups of excipients) and their ranks (certain excipients) to the initial data - investigated pharmaco-tecnological parameters of the powdered masses for tableting and to select substances-leaders from the studied groups.

Comparing the data of the study and the dispersion analysis of the fluidity of powdered mass of Galega officinalis grass extract, Vaccinium myrtillus leaf extracts and taurine correlated the largest influences on the fluidity of the powdered mass of the group of glidants [21]. Lead substances selected from the results of this study, one of which is sugar-based filler - Tablettose 80 and from the group of glidants - Neusilin US 2, have also been identified as the best in study of development of solid dosage form with Pyrola rotundifolia dry extract [18, 20].

Undoubtedly, the positive side of the conducted studies using the method of mathematical planning of the experiment is the narrowing of the total volume of studies and minimization of the number of necessary tests, which emphasizes their cost effectiveness [17].

The five-factor experiment allows us to obtain results from the influence of qualitative factors, to select the best excipients from each studied group, and to focus the pharmaceutical development attention on formulations containing leading substances. 
Study limitations. Include the inability simultaneously vary both qualitative factors and their quantitative characteristics to identify the impact on the response function in the same plan of the experiment.

Prospects for further researches. Determination of causal relationships between qualitative factors and their levels and responses, which will be the pharmaco-technological propertiesof tablets with dry extract Sanguisorba officinalis (homogeneity of tablet weight, resistance of tablets to crush, abrasion of tablets, disintegration of tablets, tableting process) manufactured by the method of direct compression of the powder mass samples tested at this stage for optimal choice of excipients of the drug, that intended to be used in the complex gastrointestinal disease therapy.

\section{Conclusions}

A five-factor experiment, a hyper-Graeco-Latin square, determined the effect of 25 excipients on the pharmaco-technological properties of powdered dry extract Sanguisorba officinalis.

Ranked rows of advantages of influence of excipients on fluidity, bulk density, density after shrinkage, angle of repose, compressibility index and Hausner ratio of powder masses with determination of leaders were constructed. Therefore, among the sugar-based fillers, the single-most leaders are Compri sugar, Tablettose 80 and Pearlitol 500 DC; among the microcrystalline cellulose-based fillers, the best results were shown by powder masses with Prosolv 90; among glidants - Neusilin US2; no leader has been identified from the studied list of disintegrants and lubricating excipients.

\section{Conflict of interests}

The authors declare that they have no conflicts of interest.

\section{References}

[1] Mezentseva, N. I., Batychenko, S. P., Mezentsev, K. V. (2018). Zakhvoriuvanist i zdorovia naselennia v Ukraini: suspilno-heohrafichnyi vymir. Kyiv: DP «Print Servis», 136.

[2] Sambukova, T. V., Ovchinnikov, B. V., Ganapol'sky, V. P., Yatmanov, A. N., Shabanov, P. D. (2017). Prospects for phytopreparations (botanicals) use in modern pharmacology. Reviews on Clinical Pharmacology and Drug Therapy, 15 (2), 56-63. doi: http://doi.org/10.17816/rcf15256-63

[3] Triantafyllidi, A., Xanthos, T., Papalois, A., Triantafillidis, J. K. (2015). Herbal and plant therapy in patients with inflammatory bowel disease. Annals of Gastroenterology, 28 (2), 210-220.

[4] Kelber, O., Bauer, R., Kubelka, W. (2017). Phytotherapy in Functional Gastrointestinal Disorders. Digestive Diseases, 35 (1), 36-42. doi: http://doi.org/10.1159/000485489

[5] Shulha, L. I., Bezkrovna, K. S., Peresadko, I. H. (2017). Zastosuvannia rodovyka likarskoho u narodnii i ofitsiinii medytsyni bazys novykh farmatsevtychnykh rozrobok. Zbirnyk naukovykh prats spivrobitnykiv NMAPO im. P. L. Shupyka, 27, $173-185$.

[6] Shulga, L. I., Bezkrovna, K. S., Beztsenna, T. S. (2018). Analysis of the segment of phytomedicines for the treatment of diseases of the gastrointestinal tract on the pharmaceutical market of Ukraine. Pharmaceutical Review, 1, 93-101. doi: http:// doi.org/10.11603/2312-0967.2018.1.8699

[7] Bezkrovna, K. S., Shulga, L. I., Domar, N. A. (2019). Pharmaco-technological and thermogravimetric researches of burnet roots in optimization of the process of obtainment of extract dry. Norwegian Journal of development of the International Science, 36 (2), 44-49.

[8] Bezkrovnaia, E. S., Shulga, L. I., Faizullin, A. V., Krasilnikova, O. A. (2019). Izuchenie protivoiazvennogo deistviia sukhogo ekstrakta krovokhlebki. Sovremennye dostizheniia farmatsevticheskoi nauki i praktiki. Vitebsk: «VGMU», 232-233.

[9] Shulga, L. I., Bezkrovna, K. S., Soldatov, D. P., Osolodchenko, T. P. (2019). Burnet roots extract dry: study of pharmaco-technological and antibacterial properties. Annals of Mechnikov Institute, 3, 39-43. doi: http://doi.org/10.5281/zenodo.3469428

[10] Helmis, M., Mohamad, B., Kumpugdee-Vollrath, M. (2016). Influence of Several Excipients on Drug Release of Tablets Containing Resveratrol. Mathews Journal of Pharmaceutical Science, 1 (2), 007.

[11] Allamneni, N., Suresh, J. N. (2014). Co-Processed Excipients as a new generation excipients with multifunctional activities: An overview. Indian Journal of Pharmaceutical Science and Research, 4 (1), 22-25.

[12] Bhor, N. J., Bhusare, S. E., Kare, P. T. (2014). Multifunctional Excipients: The Smart Excipients. International Journal of Pure \& Applied Bioscience, 2 (5), 144-148. 
[13] Derzhavna Farmakopeia Ukrainy. Vol. 1 (2015). Kharkiv: Derzhavne pidpryiemstvo «Ukrainskyi naukovyi farmatsevtychnyi tsentr yakosti likarskykh zasobiv», 1128.

[14] Ruban, O., Alkhalaf, M., Gerbina, N. (2019). Selection of a filler for tablets manufactured with direct compression method containing dry ginger extract. EUREKA: Health Sciences, 3, 26-34. doi: http://doi.org/10.21303/2504-5679.2019.00904

[15] Kambarov, Kh. Zh., Usubbaev, A. M. (2012). Razrabotka sostava i tekhnologii tabletok «Tselitel Vostoka». Vestnik farmatsii, $2(56), 45-49$.

[16] Ruban, O. A., Kolisnyk, T. Y., Slipchenko, G. D. (2018). Application of experimental design method in optimization of composition and technology for matrix tablets containing Vaccinium myrtillus leaf dry extract. Pharmaceutical Review, 2, 41-47. doi: http://doi.org/10.11603/2312-0967.2018.2.9003

[17] Hroshovyi, T. A., Martseniuk, V. P., Kucherenko, L. I., Vronska, L. V., Hureieva, S. M. (2008). Matematychne planuvannia eksperymentu pry provedenni naukovykh doslidzhen v farmatsii. Ternopil: Ukrmedknyha, 377.

[18] Darzuli, N., Hroshovyi, T., Sokolova, K., Podpletnyaya, E. (2018). Investigation of the effects of excipients on technological properties tablets of Pyrola rotundifolia extract. ScienceRise: Pharmaceutical Science, 2 (12), 43-48. doi: http:// doi.org/10.15587/2519-4852.2018.128046

[19] Ruban, O. A., Pertsev, I. M., Kutsenko, S. A., Maslii, Yu. S.; Pertseva, I. M. (Ed.) (2016). Dopomizhni rechovyny u vyrobnytstvi likiv. Kharkiv: Zoloti storinky, 720.

[20] Darzuli, N., Budniak, L., Hroshovyi, T. (2019). Selected excipients in oral solid dosage form with dry extract of Pyrola rotundifolia L. International Journal of Applied Pharmaceutics, 11 (6), 210-216. doi: http://doi.org/10.22159/ijap.2019v11i6.35282

[21] Barchuk, O. Z., Groshovyi, T. A., Zaliska, O. M., Shalata, V. J., \& Revyatsky, I. Y. (2017). Development of optimal composition and technology of tablets based on the exstract of goat's rue herb, extract of bilberry leaves and taurine by direct compression method. Pharmaceutical Review, 4, 30-40. doi: http://doi.org/10.11603/2312-0967.2017.4.8352

Received date 07.02.2020

Accepted date 18.03.2020

Published date 31.03.2020
(C) The Author(s) 2020

This is an open access article under the CC BY license (http://creativecommons.org/licenses/by/4.0). 